\title{
STRUKTUR POPULASI DAN LAJU SILANG DALAM PER GENERASI AYAM KAMPUNG DI KECAMATAN TELUK AMBON
}

\author{
Rajab*, Bercomien J. Papilaya \\ Jurusan Peternakan, Fakultas Pertanian, Universitas Pattimura \\ Jln. Ir. M. Putuhena, Kampus Poka, Ambon, Kode Pos. 97233 \\ *Email : rajab.amir@gmail.com
}

\begin{abstract}
ABSTRAK
Penelitian ini bertujuan untuk mengetahui struktur populasi, ukuran populasi aktual, ukuran populasi efektuf dan laju silang dalam (inbreeding) ayam Kampung di Kecamatan Teluk Ambon, Kota Ambon. Penelitian ini menggunakan metode survey dengan cara melakukan wawancara terhadap 60 peternak responden pada tiga desa sampel yaitu Tawiri, Hatiwe Besar dan Wayame dan pengamatan langsung di lapangan. Hasil penelitian menunjukkan bahwa jumlah ayam Kampung jantan dewasa sebanyak 558 ekor $(8,17 \%)$, ayam jantan dara 1.031 ekor $(15,10 \%)$, anak ayam jantan 1.486 ekor $(21,76 \%)$, sedangkan jumlah ayam Kampung betina dewasa sebanyak 1.451 ekor $(21,25 \%)$, ayam betina dara 1.176 ekor $(17,22 \%)$, dan anak ayam betina 1.126 ekor $(16,49 \%)$. Ukuran populasi aktual ayam Kampung sebesar 2.009 ekor dan ukuran populasi efektifnya 1.612 ekor. Laju silang dalam per generasi ayam Kampung sebesar 0,000310\%.
\end{abstract}

Kata kunci: Struktur populasi, laju silang dalam per generasi, ayam kampung

\section{POPULATION STRUCTURE AND INBREEDING RATE PER GENERATION OF DOMESTIC FOWL IN TELUK AMBON DISTRICT}

\begin{abstract}
The objective of this research was to know both the population structure and the inbreeding rate per generation of native fowl in Teluk Ambon District Ambon Regency. This study was conducted by using survey method with purposive random sampling of 60 farmers/breeders from Tawiri, Hatiwe Besar and Wayame villages. The variables observed were the number of adult male chicks $(\mathrm{Nm})$, number of adult female chicks (Nf), number of young male and young female chicks, actual population size $(\mathrm{Na})$, effective population size $(\mathrm{Ne})$, and the rate of inbreeding per generation $(\Delta \mathrm{F})$. The results showed that structure population of the domectic fowl in Teluk Ambon district include the number of adult male chicks 558 tail $(8,17 \%)$, young male chicks 1031 tail $(15,10 \%)$, male of DOC 1486 tail $(21,76 \%)$, whereas the number of female were 1451 tail $(21,25 \%), 1176$ tail $(17,22 \%)$, and 1126 tail $(16,49 \%)$ respectively for adult, young and DOC. Actual population size of domestic fowl was 2009 tail and the size of population effective was 1612 tail. The rate of inbreeding per generation was $0.000310 \%$.
\end{abstract}

Key words: Population structure, inbreeding rate per generation, domestic fowl

\section{PENDAHULUAN}

Ayam peliharaan dari daerah tropis merupakan sumber pangan paling penting di dunia. Namun, usaha peternakan ayam lokal belum berkembang antara lain karena belum tersedianya bibit unggul serta cara budi daya yang tidak efisien (National Research Council, 1993 dalam Nataamijaya, 2010). Di negara berkembang, usaha ternak ayam lokal berperan penting dalam meningkatkan pendapatan masyarakat karena usaha tersebut melibatkan sebagian besar penduduk miskin (Sonaiya, 2007). Indonesia kaya akan sumber daya genetik ternak (SDGT) atau animal genetic resources (AnGR) yang merupakan bagian dari keanekaragaman hayati (biodiversity) dunia yang tidak hanya memiliki manfaat saat ini tetapi juga untuk masa depan, termasuk diantaranya berbagai rumpun ayam lokal yang tersebar di hampir seluruh wilayah kepulauan nusantara. Berdasarkan hasil riset Lembaga Ilmu Pengetahuan Indonesia (LIPI), yang mengidentifikasi berbagai ayam lokal yang ada di Indonesia dengan menggunakan teknik molekuler fragment DNA D-loop mitokondria, diketahui bahwa Indonesia merupakan salah satu pusat domestikasi ayam di dunia setelah China dan India (Widjastuti dkk., 2012). Ayam lokal tersebut mempunyai 
penampilan yang spesifik seperti ayam Kedu, Sentul, Pelung, Gaok, Nunukan dan Merawang, tetapi ada juga yang tidak spesifik dan sangat beragam penampilannya yaitu ayam Kampung (Sulandri dkk., 2007).

Penampilan ayam Kampung sangat beragam, begitu pula sifat genetiknya, penyebarannya sangat luas karena populasi ayam Kampung dijumpai di kota maupun desa. Potensinya patut dikembangkan untuk meningkatkan gizi masyarakat dan menaikkan pendapatan keluarga (Diwyanto \& Priyanti, 2009). Diakui atau tidak selera konsumen terhadap ayam Kampung sangat tinggi. Dalam 10 tahun terakhir konsumsi daging dan telur ayam lokal justru lebih diminati oleh masyarakat menengah ke atas atau kaum urban (Zulkarnain, 2007 dalam Wibowo, 2012). Namun demikian perhatian dan pemanfaatan ayam Kampung yang kita punyai masih sangat rendah. Hal tersebut dapat dilihat dari perkembangan populasi yang fluktuatif, produksi telur dan daging ayam Kampung yang diusahakan peternak relatif rendah. Faktor penyebabnya antara lain sistem pemeliharaan tradisional yang berdampak pada angka kematian ayam dapat mencapai $70 \%$ (Rajab dan Papilaya, 2012), mutu bibit yang rendah, adanya sifat mengeram, sistem pemeliharaan yang masih tradisional dan pemberian pakan yang seadanya (Iskandar, 2012; Resnawati, 2012). Pemeliharaan yang umumnya masih bersifat tradisional dapat berdampak terhadap tingginya laju silang dalam pada perkawinan ayam.

Silang dalam atau inbreeding adalah perkawinan antara dua individu yang masih mempunyai hubungan kekerabatan. Dua individu dikatakan berkerabat atau mempunyai hubungan keluarga, bila kedua individu tersebut memiliki satu atau lebih moyang bersama (common ancestor) dalam 6 sampai 8 generasi ke atas (Hardjosubroto, 1994). Laju inbreeding akan semakin besar bila jumlah ternak betina jauh lebih banyak dibandingkan ternak jantan. Setiap kenaikan 10\% koefisien inbreeding akan menurunkan $4 \%$ bobot badan pada ternak. Penelitian lain menunjukkan akibat silang dalam terjadi penurunan bobot sapih sebesar $0,111 \mathrm{~kg}$ pada rata-rata koefisien inbreeding sebesar $16 \%$. Artinya menurunnya performans ternak sebagai akibat depresi silang dalam (inbreeding depression) (Lamberson dan Thomas, 1984). Apabila program pemuliaan akan berjalan lambat diduga terdapat peningkatan koefisien inbreeding.

Beberapa cara untuk mengurangi inbreeding dalam teknisnya di lapangan yaitu dengan memperbesar populasi, mengarahkan pola perkawinan, membatasi seleksi, meningkatkan nilai heritabilitas individu, titik berat program pemuliaan berdasar informasi famili, penggunaan indeks yang setara dalam menduga nilai pemuliaan (Haley, 1994). Peningkatan populasi, produksi dan efisiensi usaha ayam Kampung, perlu ditingkatkan dari tradisional ke arah agribisnis (Zakaria, 2004). Penelitian ini dilaksanakan dengan tujuan untuk mengetahui struktur populasi, ukuran populasi aktual, ukuran populasi efektuf dan laju silang dalam (inbreeding) ayam Kampung di Kecamatan Teluk Ambon Kota Ambon.

\section{BAHAN DAN METODE}

Penelitian ini berlangsung dari bulan Desember 2017 sampai Februari 2018, dan pengambilan data lapangan dilaksanakan di tiga lokasi yaitu desa Tawiri, Hatiwe Besar dan Wayame, Kecamatan Teluk Ambon, Kota Ambon. Pertimbangan pemilihan lokasi tersebut adalah (1) sebagian besar penduduknya bekerja di sektor pertanian dengan pemeliharaan ayam Kampung sebagai usaha sambilannya, (2) memiliki populasi ayam Kampung paling banyak dibanding desa lainnya, dan (3) terdapat kelompok tani ternak yang pernah mendapatkan bantuan dana dan atau pelatihan manajemen usaha baik dari pemerintah kota Ambon dan provinsi Maluku maupun Tim pelaksana program Pengabdian kepada Masyarakat (PkM) Universitas Pattimura dalam rangka pengembangan ayam Kampung.

Materi dalam penelitian ini adalah sampel sumber daya ternak ayam Kampung dalam kaitannya dengan pengukuran populasi dan laju silang dalam (inbreeding) per generasi. Peralatan yang di gunakan dalam penelitian ini adalah kuisioner dan alat tulis menulis. Penelitian ini menggunakan metode survey dengan cara melakukan wawancara terhadap peternak responden dan pengamatan langsung di lapangan. Penentuan desa sampel dilakukan secara purposive sampling sesuai dengan pertimbangan seperti disebutkan di atas. Pada masing-masing desa sampel tersebut dipilih secara purposive sampling 20 responden peternak ayam Kampung dengan pertimbangan yaitu : (1) memiliki pengalaman beternak di atas 3 tahun, dan (2) mempunyai populasi ayam Kampung lebih dari 30 ekor.

Variabel yang diamati dan dihitung antara lain : (a) struktur populasi ayam Kampung (meliputi : jumlah anak ayam jantan (ekor), jumlah anak ayam betina (ekor), jumlah ayam jantan dara (ekor), jumlah ayam betina dara (ekor), jumlah ayam jantan dewasa (ekor), dan jumlah ayam betina dewasa (ekor)) ; (b) jumlah populasi actual (Na) ; (c) jumlah populasi efektif $(\mathrm{Ne})$; dan (e) laju silang dalam (inbreeding) per generasi $(\Delta \mathrm{F})$.

Data yang diperoleh dianalisis secara deskriptif, baik kuantitatif maupun kualitatif. Untuk mengetahui jumlah populasi aktual $(\mathrm{Na})$ dihitung dengan jumlah ayam jantan dewasa ditambahkan dengan jumlah ayam jumlah ayam betina dewasa (Salamena dkk., 2007; Rusfidra dkk., 2012), yang dapat ditulis dengan persamaan sebagai berikut :

$$
N a=N m+N f
$$

Ukuran populasi efektif ( $\mathrm{Ne}$ ) dihitung dengan rumus menurut Falconer dan MacKay (1996) sebagai berikut : 


$$
\mathrm{Ne}=\frac{(4 \mathrm{Nm} \mathrm{Nf})}{\mathrm{Nm}+\mathrm{Nf}}
$$

Laju silang dalam (inbreeding) per generasi dihitung berdasarkan rumus menurut Ponzoni (1997), Hamilton (2009), sebagai berikut :

$$
\Delta \mathrm{F}=\frac{1}{2 \mathrm{Ne}}
$$

Dimana: $\mathrm{Nm}=$ Jumlah ayam jantan dewasa (number of breed male).

$\mathrm{Nf}=$ Jumlah ayam betina dewasa (number of breed female).

$\mathrm{Na}=$ Jumlah populasi actual.

$\mathrm{Ne}=$ Jumlah poipulasi efektif.

$\Delta \mathrm{F}=$ Laju silang dalam (inbreeding) per generasi.

\section{HASIL DAN PEMBAHASAN}

\section{Struktur Populasi Ayam Kampung Di Kecamatan Teluk Ambon}

Struktur populasi merupakan susunan sekelompok organisme yang mempunyai spesies sama (takson tertentu) serta hidup dan menempati kawasan tertentu pada waktu tertentu. Struktur populasi pada ternak mencakup indukan, pejantan, ternak jantan dan betina muda, serta anak jantan dan betina. Struktur populasi perlu diketahui sebagai suatu parameter dalam mengatur sistem pemuliabiakan, manajemen pemeliharaan dan juga sebagai data dasar tentang jumlah populasi di peternakan rakyat. Dengan demikian dapat diketahui berapa induk betina dan betina muda produktif serta rasio antara induk betina dan betina muda dengan pejantan (Tobing, 2008 dalam Utami, 2015).

Data struktur populasi ayam Kampung di Kecamatan Teluk Ambon Kota Ambon seperti tertera pada Tabel 1. Hasil penelitian menunjukkan bahwa jumlah populasi ayam Kampung di kecamatan Teluk Ambon sebesar 6.828 ekor, dimana kepemilikan paling banyak terdapat di desa Wayame yaitu sebesar 2.691 ekor, diikuti desa Tawiri dan Hatiwe Besar dengan jumlah populasi ayam Kampungnya masing-masing sebesar 2.215 dan 1.922 ekor. Bila dihitung berdasarkan jumlah responden maka rata-rata kepemilikan ayam Kampung yaitu sebesar 135, 111, dan 96 ekor per peternak masing-masing untuk desa Wayame, Tawiri dan Hatiwe Besar. Hasil wawancara dengan responden peternak bahwa jumlah populasi ayam Kampung yang lebih tinggi di Desa Wayame, karena adanya permintaan konsumen akan komoditi telur, DOC maupun ayam bibit terutama dari daerah Papua, sedangkan produk ayam Kampung berupa daging dan telur dari desa Tawiri dan Hatiwe Besar umumnya dipasarkan dalam wilayah kota Ambon, sehingga ada sebagian responden yang menjadikan usahatani ayam Kampung sebagai pekerjaan pokoknya. Beberapa laporan mengenai pengkajian usahatani ayam Kampung, yang menempati populasi terbanyak di antara ayam-ayam lokal lain, menunjukkan bahwa ayam Kampung mempunyai beberapa kelebihan yang diapresiasi masyarakat, sehingga eksistensinya dipertahankan. Kelebihan tersebut antara lain harga jual satuan produk lebih tinggi dibandingkan dengan ayam ras (Iskandar, 2006).

Tabel 1. Struktur populasi ayam Kampung di Kecamatan Teluk Ambon,Kota Ambon

\begin{tabular}{lccccccc}
\hline \multirow{2}{*}{ Desa } & \multicolumn{2}{c}{ Anak Ayam (ekor) } & \multicolumn{2}{c}{ Ayam Dara (ekor) } & \multicolumn{2}{c}{ Ayam Dewasa (ekor) } & \multirow{2}{*}{$\begin{array}{c}\text { Total } \\
\text { (ekor) }\end{array}$} \\
\cline { 2 - 7 } & Jantan & Betina & Jantan & Betina & Jantan & Betina & 2.215 \\
Tawiri & 439 & 474 & 294 & 333 & 196 & 479 & 1.922 \\
Hatiwe Besar & 412 & 311 & 326 & 351 & 148 & 374 & 2.691 \\
Wayame & 635 & 341 & 411 & 492 & 214 & 598 & 6.828 \\
\hline Total (ekor) & 1486 & 1126 & 1031 & 1176 & 558 & 1451 & 100,00 \\
Total (\%) & 21,76 & 16,49 & 15,10 & 17,22 & 8,17 & 21,25 & \\
\hline
\end{tabular}

Hasil survey seperti tertera pada tabel 1 memperlihatkan secara keseluruhan di kecamatan Teluk Ambon terdapat jumlah ayam Kampung jantan dewasa sebanyak 558 ekor $(8,17 \%)$, ayam jantan dara 1.031 ekor $(15,10 \%)$, anak ayam jantan 1.486 ekor $(21,76 \%)$, sedangkan jumlah ayam Kampung betina dewasa sebanyak 1.451 ekor $(21,25 \%)$, ayam betina dara 1.176 ekor $(17,22 \%)$, dan anak ayam betina 1.126 ekor $(16,49 \%)$. Jika dihitung maka rasio ternak jantan dan betina untuk ayam Kampung kategori umur dewasa sebesar $1: 2,6$, ayam dara $1: 1,14$, dan anak ayam $1: 0,76$. Jumlah ayam betina dewasa yang lebih banyak karena digunakan sebagai induk dalam pembibitan ayam untuk menghasilkan ayam muda yang akan dijual, disamping ada sebagian responden yang menjadikan ayam betina tersebut untuk tujuan produksi telur tetas maupun telur komersil.

Ukuran Populasi Aktual, Ukuran Populasi Efektif dan Laju Silang Dalam Per Generasi Ayam Kampung Di Kecamatan Teluk Ambon

Data analisis ukuran populasi aktual, ukuran populasi efektif dan laju silang dalam per generasi ayam Kampung di Kecamatan Teluk Ambon hasil 
penelitian ini seperti tertera pada tabel 2. Hasil penelitian menunjukkan bahwa jumlah populasi aktual ayam Kampung di kecamatan Teluk Ambon sebesar 2.009 ekor, dimana ayam Kampung dengan populasi aktual paling banyak terdapat di desa Wayame yaitu sebesar 812 ekor, diikuti desa Tawiri dan Hatiwe Besar dengan jumlah populasi ayam Kampungnya masingmasing sebesar 675 dan 522 ekor. Secara keseluruhan pada ketiga desa sampel, peternak umumnya memelihara ayam betina dalam jumlah lebih banyak dibanding ayam jantan, karena selain digunakan sebagai bibit juga digunakan untuk produksi telur komersial. Subandriyo (2003) dalam Rusfidra dan Hasibuan (2012) menjelaskan bahwa populasi aktual adalah jumlah ternak jantan dan betina dewasa (parent stock) yang digunakan untuk proses perkawinan yang akan menghasilkan DOC, (bibit/keturunan) yang merupakan calon-calon pejantan dan induk.

Ukuran populasi efektif (Ne) ayam Kampung di Kecamatan Teluk Ambon, kota Ambon adalah 1612 ekor. Hasil penelitian menunjukkan bahwa ukuran populasi efektif ayam Kampung di kecamatan Teluk Ambon masih jauh berada di bawah ukuran populasi aktualnya yaitu dengan selisih sebesar 397 ekor. Laju silang dalam (inbreeding) per generasi ayam Kampung di Kecamatan Teluk Ambon adalah sebesar 0,000310\%. Merujuk pada Salamena dkk. (2007) yang menyatakan bahwa suatu populasi dapat bertahan apabila laju silang dalam per generasi lebih kecil atau sama dengan 1\%, maka hasil penelitian ini menunjukkan bahwa tekanan silang dalam (inbreeding) dari populasi ayam Kampung di Kecamatan Teluk Ambon belum terjadi. Peralihan sistem pemeliharaan dari cara tradisional ke sistem semi-intensif dengan pengaturan tatalaksana perkembangbiakkan dan penanganan kesehatan ayam oleh sebagian peternak responden selain berguna untuk menjaga kelangsungan populasi, meningkatkan populasi juga dapat mengurangi angka kematian ayam yang cukup tinggi. Selain ini ada juga responden peternak di desa Wayame yang membagi-bagikan ayam Kampung miliknya kepada teman-teman peternaknya untuk menjaga keberlangsungan populasi ayam Kampung bila sewaktu-waktu musim penyakit ayam (tetelo atau ND) datang. Cara ini pun dapat memperkecil kemungkinan terjadinya silang dalam dalam populasi ayam Kampung karena adanya perkawinan antara sub populasi ayam Kampung yang berbeda (outbreeding), sehingga pada akhirnya keberlangsungan keberadaan populasi ayam Kampung tetap terpelihara dan produktivitasnya tidak menurun. Praharani dkk. (2009) menyatakan bahwa kenaikan $1 \%$ dari tingkat inbreeding per generasi akan menurunkan produksi dan menyebabkan penurunan sifat performans pada ternak.

Tabel 2. Ukuran populasi aktual (Na), ukuran populasi efektif ( $\mathrm{Ne}$ ) dan laju silang dalam (inbreeding) per generasi ayam Kampung di Kecamatan Teluk Ambon

\begin{tabular}{clcccc}
\hline \multirow{2}{*}{ No } & \multicolumn{1}{c}{ Peubah } & \multicolumn{3}{c}{ Desa } & \multirow{2}{*}{ Total } \\
\cline { 2 - 4 } & & Tawiri & Hatiwe Besar & Wayame & \\
\hline \multirow{2}{*}{1} & $\begin{array}{l}\text { Jumlah Ayam Jantan Dewasa (Number } \\
\text { of breed male, Nm). (ekor }\end{array}$ & 196 & 148 & 214 & 558 \\
2 & $\begin{array}{l}\text { Jumlah Ayam Betina Dewasa (Number } \\
\text { of breed female, Nf). (ekor). }\end{array}$ & 479 & 374 & 598 & 1451 \\
3 & Jumlah Populasi Aktual (Na) (ekor). & 675 & 522 & 812 & 2.009 \\
4 & Jumlah Populasi Efektif (Ne) (ekor). & 556 & 424 & 630 & 1.612 \\
5 & Laju Inbreeding per Generasi ( $(\mathrm{F})(\%)$. & 0,000899 & 0,001179 & 0,000793 & 0,000310 \\
\hline
\end{tabular}

\section{SIMPULAN}

Kesimpulan yang dapat ditarik dari penelitian ini adalah : (1) Struktur populasi meliputi jumlah ayam Kampung jantan dewasa sebanyak 558 ekor $(8,17 \%)$, ayam jantan dara 1.031 ekor $(15,10 \%)$, anak ayam jantan 1.486 ekor $(21,76 \%)$, sedangkan jumlah ayam Kampung betina dewasa sebanyak 1.451 ekor $(21,25$ $\%)$, ayam betina dara 1.176 ekor $(17,22 \%)$, dan anak ayam betina 1.126 ekor (16,49\%). (2) Ukuran populasi aktual ayam Kampung sebesar 2.009 ekor dan ukuran populasi efektifnya 1.612 ekor. (3) Laju silang dalam per generasi ayam Kampung sebesar 0,000310.

\section{DAFTAR PUSTAKA}

Diwyanto, K., dan A. Priyanti. 2009. Pengembangan Industri Peternakan Berbasis Sumber Daya Lokal. Prosiding Pengembangan Inovasi Pertanian. 2: 208-228.

Falconer, D. and T.F.C. Mac Kay. 1996. Introduction to Quantitative Genetics. Fourth Edition. England: Longman Group. Ltd.

Haley, C. 1994. Inbreeding: Animal Breeding 2, Second Edition. London: Rostin Institut.

Hamilton, M. B. 2009. Population Genetics. West Sussex, UK: Blackwell Publishing, John Wiley \& Sons Ltd. 
Hardjosubroto, W. 1994. Aplikasi Pemuliabiakan Ternak Di Lapangan. Jakarta: PT. Grasindo (Gramedia Widiasarana Indonesia).

Iskandar, S. 2006. Strategi Pengembangan Ayam Lokal. Wartazoa. 16(4): 190-197.

Iskandar, S. 2012. Optimalisasi Protein dan Energi Ransum untuk Meningkatkan Produksi Daging Ayam Lokal. Prosiding Pengembangan Inovasi Pertanian. 5: 96-107.

Lamberson, W. R., and D. L. Thomas. 1984. Effect of Inbreeding in Sheep: A review. J. Anim. Breeding. 52: 287 - 297.

Nataamijaya, A. G. 2010. Pengembangan Potensi Ayam Lokal untuk Menunjang Peningkatan Kesejahteraan Petani. J. Litbang Pertanian. 29(4): 131-138.

Ponzoni, R.W. 1997. Genetic Resources and Conservation. In: Piper, L. and A. Ruvinsky (Eds by). The Genetic of Sheep, p.437-469. New York: CABI Publishing.

Praharani, L. E. Juarni dan L. G. M. Budiarsana. 2009. Parameter indikator inbreeding rate pada populasi ternak kerbau di Kabupaten Lebak Provinsi Banten. Makalah pada Seminar dan Lokakarya Nasional Kerbau. Bogor.

Rajab, dan B. J. Papilaya. 2012. Sifat Kuantitatif Ayam Kampung Lokal Pada Pemeliharaan Tradisonal. J. Agrinimal. 2(2): 61-64.

Resnawati, H. 2012. Inovasi Teknologi Pemanfaatan Bahan Pakan Lokal Mendukung Pengembangan Industri Ayam Kampung. Prosding Pengembangan Inovasi Pertanian. 5: 79-95.

Rusfidra, R. Zein, dan A. M. A. Hasibuan. 2012. Ukuran Populasi Efektif, Ukuran Populasi
Aktual dan Laju Inbreeding Per Generasi Itik Lokal di Kecamatan Tilatang Kamang Kabupaten Agam. J. Peternakan Indonesia. 14(3): 461-465.

Salamena, J. F., R. R. Noor, C. Sumantri, dan I. Inounu. 2007. Hubungan Genetik, Ukuran Populasi Efektif, dan Laju Silang Dalam Per Generasi Populasi Domba Di Pulau Kisar. $J$. Indonesian Tropical Animal Agriculture. 32 (2): 71-75.

Sonaiya, E. B. 2007. Family Poultry, Food Security and The Impact of HPAI. J. World's Poultry Science. 63: 132-138.

Sulandri, S., M.S.A Zein, Sri Paryanti, T. Sartika, J.H.P. Sidadolog, M. Astuti, T. Widjastuti, E. Sujana, S. Darana, I. Setiawan, D. Garnida, S. Iskandar, D. Zainuddin, T. Herawati, I. Wayan \& T. Wibawan. 2007. Keanekaragaman Sumber Daya Hayati Ayam Lokal Indonesia. Manfaat dan Potensi. Pusat Penelitian Biologi LIPI. Jakarta.

Utami, E.U. 2015. Struktur Populasi Sapi Bali Di Peternakan Rakyat Kelurahan Sapaya Kabupaten Gowa. [Skripsi]. Makassar: Fakultas Peternakan, Universitas Hasanuddin.

Wibowo, B. 2016. Dinamika Kinerja Agribisnis Ayam Lokal di Indonesia. Wartazoa. 26(4): 191202.

Widjastuti, T., I.Y. Asmara, dan A. Anang. Pengembangan Ayam Lokal Di Indonesia. Prosiding Seminar Nasional Pengembangan Unggas Lokal Di Indonesia. 1: 15-22.

Zakaria, S. 2004. Pengaruh Luas Kandang terhadap Produksi dan Kualitas Telur Ayam Buras yang Dipelihara dengan Sistem Litter. Buletin Nutrisi dan MakananTernak. 5(1): 1-11.

Available online at journal homepage: http://ojs3.unpatti.ac.id/index.php/agrinimal 